Rocznik Komparatystyczny - Comparative Yearbook

6 (2015)

D0I: 10.18276/rk.2015.6-19

Marta Anna Skwara

The University of Szczecin

\title{
How Can One Write National Literature History in a "Glocal" World? Remarks on the Writing of a Modern Polish Literature Handbook in English
}

Polish literature is far from being unrecognized in the world. In the $20^{\text {th }}$ century four Polish writers and poets were elevated to the rank of Noble Prize laureates: Henryk Sienkiewicz (1905), Władysław Reymont (1924), Czesław Miłosz (1980) and Wisława Szymborska (1996). Still, Polish literature remains largely unknown outside of Poland's borders. While being a European literature in its own eyes, it is usually described by outsiders as being one of the Eastern European (or East-Central European) literatures. Such umbrella terms not only deprive it of its individual features but also of the Western European and transatlantic connections which have been so important for its development. Perhaps the iron curtain that isolated Polish literature for almost 50 years, in the period of the so-called People's Democracies established in Eastern and Central Europe by the Soviet system, still makes itself felt. However, the political predicament had its more positive outcome too: a world-wide Polish emigration creating its own literary culture(s), modes of expression, and bilingual and intercultural authors and works. A modern handbook of Polish literature, supposed to address both foreign and Polish readers, should therefore consider two aspects together that are usually kept separate. It should give an account of the long internal tradition of Polish literature - its roots, language and development - but it should also describe its equally long but often forgotten European and transatlantic contexts. The handbook should cover both the inner mechanisms and the outer relationships of Polish literature, both its traditional 
forms, genres, themes and the new ones, those that have been developing in the multicultural world, nowadays also in the multicultural web. The balance between tradition and (post)modernity, local and global, should enable foreign readers to acquire some perspective on one of the relatively unknown European literatures, while domestic readers should be helped to see their well-known literature from different cultural angles. And, of course, the handbook should be understandable and attractive to any modern student of literature.

I am presently preparing a one-volume English-language history of Polish literature. In this paper I will explain how I plan to organize my account, and at the same time I will discuss several issues connected with the writing of such a handbook. Hopefully, my paper can illustrate some of the problems of presenting a "local" literature on the global literary-history market today.

Since my monograph is supposed to give a foreign reader/student of literature an orientation about the historical development of Polish literature as well as its modern status, the work will have to cover a time span of about eight centuries, from the first Latin-Polish and Polish literary texts produced in the $13^{\text {th }}$ and $14^{\text {th }}$ centuries until today. Yet the objective is to give the reader a rich and attractive but concise compendium; for that reason, most historical, literary and biographical data will be relegated to chronological tables in an appendix to the monograph. The appendix will also contain maps showing the different shapes of the country over the centuries, and its various literary centers (also emigrant centers like Paris in the $19^{\text {th }}$ century, or London in the $\left.20^{\text {th }}\right)$. Summaries of main novels and longer literary texts will be provided in the appendix, offering the necessary background for my cross-epoch and cross-culture analyses.

In the introduction to the monograph I intend to discuss existing ways of presenting Polish literature internationally. I shall particularly attend to the manner in which Polish literature was (superficially) incorporated into bigger literary areas and discussed under such umbrella concepts as "Slavic literatures" or "Central", "East-Central", or "East-European" literatures. The concept of "minor" and "major" literatures, which often plays a misleading role when the literatures of Europe are presented to European and non-European readers will also be discussed in the introduction. I would like to emphasize the importance of seeing Polish literature as one European literature among other European 
literatures, sharing with western Europe a common literary language (Latin) for several centuries, and always sharing the same Greco-Roman-Biblical roots. Polish literature has also displayed the same repertory of themes, motifs and literary genres, though adapting and developing them in its own original way, and the same modern understanding of what literature is and how it operates. It is quite obvious to Polish literary scholars that our literature cannot be fully understood without attention to its connections with Western European literatures on the one hand and Russian literature, together with Lithuanian, Ukrainian and Belorussian folk and literary traditions, on the other. The importance of the literary contacts with the literatures of southern and northern Europe are equally obvious but often overlooked when the Slavic-literatures or East-European-literature perspective is applied.

An outstanding example of the many-sided transcultural connections of Polish literature is Juliusz Słowacki, one of our most imaginative romantic poets and playwrights who, partly due to his sophisticated and deeply metaphoric Polish, still unfortunately remains just a "Polish" author (Brandes, 2009: 63), as Georg Brandes put it more than a century ago in his famous essay "Weltliteratur" (1899). Yet Słowacki based his plays on Shakespeare's and Calderon de la Barca's works, introducing a sophisticated intertextual play in the modern sense of the term. And he populated such plays with figures - like Wernyhora - taken from Ukrainian folk tradition. On the other hand Słowacki referred to the figure of the Nordic bard as well as to the figure of the Biblical prophet in his writings. His symbolical prophecies were sometimes set in legendary Slavic history (for example in his drama Lilla Weneda) but sometimes in the mythologized multicultural Siberia where Polish fighters for freedom were sent by the czars (as in his long poem "Anhelli").

In the case of Polish literature, the cross-cultural discussion often inevitably merges with a political discussion. That is the case, for instance, where our Romantic literature is concerned, as it was created in a politically non-existing country (in the years 1795-1918 Poland was partitioned among the Russian, German and Austrian empires). For that reason, it would be good to highlight, at the end of the introductory chapter, one of the most important literary-political crossroads, namely the seemingly intercultural literary area of "the literature of the people's democracies", artificially constructed in the second half of the 
$20^{\text {th }}$ century in the Soviet bloc. In that context, the political control of literary production in this area should be taken up, as well as the divided circuits of literary circulation during this period: circulation inside and outside the country (national/ immigrant literature) and, at the same time, official and unofficial circulation inside the country (legal/ illegal literature). Both the immigrant and the illegal Polish literature of the second half of the $20^{\text {th }}$ century were openly connected with the Western tradition of freedom of thought and expression, and both currents produced literary works displaying the mechanisms of political oppression and worldwide struggle for freedom - as in the case of the vivid description of the Soviet Gulags by an immigrant Polish author working in Italy, Gustaw Herling-Grudziński. His excruciating novel A World Apart: A Memoir of the Gulag, 1951, was first published in English with a foreword by Bertrand Russell, only then in Polish (Inny świat. Zapiski sowieckie. London, 1953). The novel has now been translated into many languages, including Chinese.

After having emphasized the European and world contexts of Polish literature in my introduction, I plan to go on to demonstrate - in the first chapter - the differentia specifica of that literature. I have already mentioned some such features: the $19^{\text {th }}$ century literature of the politically non-existing Poland with its romantic and so-called "positivistic" culture, literature and ideas (for instance, romantic Messianism/ Prometheanism of Biblical and ancient origin on the one hand, and positivistic "organic work" based on European philosophy on the other). The strong tradition of double-coded Aesopian literary language was also developed then - due to the need of circumventing political (mostly Russian) censorship - and in fact this Aesopian language was in operation until the fall of Communism almost two centuries later (1989).

It is worth noting that keeping and developing a national language and a national literature was quite a unique phenomenon in the Central Europe of the $18^{\text {th }}$ and $19^{\text {th }}$ centuries, where some nations were almost deprived of their language by foreign domination (like the Czechs, culturally dominated by Germans), while others kept producing literature in Latin up to the $19^{\text {th }}$ century (like the Hungarians and Bulgarians). When describing specific features of Polish literature and culture I will also dwell on the $17^{\text {th }}$ century culture and literature of the gentry with its special ideology ("Sarmatism" - based on the belief in Polish origins in the ancient land of Parts that culturally connected 
the West and East of Europe), unique traditions (such as extremely elaborated funeral customs and pompa funebris) and specific literary genres such as gawęda szlachecka, a gentry tale. The latter is well-known to the world in the form in which Joseph Conrad - an English author of Polish origin, one of our political émigrés - introduced it into the modern novel. The monologues of Marlow, Conrad's famous character, have a lot in common with the traditional Polish gentry tale that used to be told for long hours (or even days) during family and social meetings.

In addition, in the chapter on genres and themes characteristic of Polish literature, it seems important to analyze some typical Polish literary myths/ motifs. Particularly the ones grouped around the notions of Christianity (e.g., Polska przedmurzem chrześcijaństwal Poland as the antemurale christianitatis) and traditional tolerance. For instance, in the $16^{\text {th }}$ century Poland was called państwo bez stosów ("the country without stakes") since religious dissenters were not burnt at the stakes in the multicultural Polish-Lithuanian Res Publica, unlike in the rest of Europe in the epoch. Various patriotic motifs that contributed to the creation of the specific Polish cult of death, present in our literature and art ever since the Renaissance, will also be discussed. They were often set in international contexts, for example, the patriotic song La Varsovienne with its famous refrain Hej, kto Polak na bagnety!/ Polonais, à la baïonnette! that alluded to the French national anthem La Marseillaise and was in fact written by a French enthusiast of the Polish November Uprising against Czarist Russia in 1831.

I should like to pay attention not only to the ways in which such literary myths/motifs were constructed in previous epochs but also to the manners in which they were deconstructed by modern poets and writers at the turn of the $20^{\text {th }}$ century. A good example here could be a novel by the young author Dorota Masłowska (18 at the time of the novel's publication - 2002) Wojna polsko-ruska pod flaga biato-czerwona ("Polish-Soviet War under the white and red flag" [that is the Polish flag]). The authoress creates a pandemonium of Polish heroic myths through a vivisection of literary language and a deconstruction of the traditional mentality out of which no new constructions appear. The novel is emblematic of the hard times of transition from the old People's Poland integrated into the Soviet bloc to the new "European Union" Poland with no firm ground whatsoever. Since the novel has been adapted for the 
cinema, and since an international audience nowadays has relatively easy access to movies produced in various language versions, it would be productive, here and in many other cases of literature adapted for the cinema, to dwell on the interpretation of the movie in the context of intermediality.

The chapter on typically Polish motifs or genres will be followed by a chapter devoted to multicultural aspects of Polish literature. I should like to begin with the Latin-Polish literature of the Middle Ages and go on to discuss the intercultural literature produced in Poland over the centuries in Polish as well as in other languages, most of all Yiddish. The best known example of the latter is no doubt the novels of Isaac Bashevis Singer (Icek-Hersz Zynger, Icchok Baszewis). He made his literary debut in Yiddish in interwar Poland (1925) and published his first big novel while still in Poland (in 1933-34). It was followed by many subsequent novels, written in Yiddish but set in Eastern Poland and published in English in the US, where he emigrated in 1935.

Some literary areas where different languages mingled and co-existed will also be discussed in detail in the chapter. One example is $19^{\text {th }}$ century Galicia, which was an important part of The Res Publica of Two Nations (Polish and Lithuanian) until the partitions of Poland in the $18^{\text {th }}$ century. Fom the first partition of Poland (1772) up to the end of WWI, Galicia formed part of the Habsburg Empire, now divided between Poland and Ukraine. One Galician author who will certainly be introduced is Bruno Schulz, a Polish writer of Jewish origin, who created in Polish a magical world of his own out of Polish, Jewish and biblical traditions in the Galician Drohobycz (a Polish town in the 1920s and 1930s, now Ukrainian). I will also look at the literatures of national and cultural minorities and try to demonstrate how those literatures were incorporated into or excluded from mainstream Polish literature. That will give me an opportunity to comment on Polish authors who, for various reasons, chose to write wholly or partly in other languages than Polish: Mikołaj Sarbiewski (Latin), Jan Potocki (French), Józef Korzeniowski / Joseph Conrad (English), Jerzy Kosiński (English), Witold Gombrowicz (Spanish) - and to look at them in the perspective of European and world literature.

The third, fourth and fifth chapters of my Polish literature handbook will be devoted to Polish poetry, prose and drama respectively. The basic idea will be to describe the poets, writers and playwrights and their works as engaged in 
a literary, often intercultural, dialogue over the ages. Thus, for instance, it will be demonstrated how the leading Renaissance poet Jan Kochanowski, whose poetry relied on Greek and Roman traditions, was read by other canonic (and non-canonic) Polish poets. Among these was Adam Mickiewicz, who in his turn became a titanic figure for later Polish poets (including the $20^{\text {th }}$ century Nobel Prize laureates Czesław Miłosz and Wisława Szymborska) and who has not stopped appealing to the youngest poetic generation. Since several Polish poets became international stars of poetry - which is undoubtedly true of two renowned international professors of literature: Adam Mickiewicz in $19^{\text {th }}$ century Paris and Czesław Miłosz in $20^{\text {th }}$ century Berkeley, California - I would also like to present their achievements in promoting and presenting Polish and international poetry. In the case of Mickiewicz and his Paris Lectures it was mostly Slavic and European poetry, in the case of Miłosz and his Wypisy z ksiag uzytecznych (1994)/ A Book of Luminous Things (1996) it was the presentation of world poetry. The latter book is an interesting personal anthology of "realistic" poetry, to use the poet's definition, translated by Miłosz and with brief comments by him. After the 1921 translation of the Chinese Flute by another canonic Polish poet, Leopold Staff, it was the first time in Polish literary history that so many Chinese poems were made available for a domestic readership. In addition, Miłosz let them be accompanied by Polish and world poetry, and he presented that collection almost simultaneously to Polish and to international readers. Both the Polish and English version of Miłosz's anthology, even though slightly different, reserved some special space for Chinese classical poems, Miłosz's favourites. Miłosz's book must have deeply affected modern Polish poets as a passage from "Głębia zmierzona chińskim pędzlem”, 1998 ("The Depth Measured with a Chinese Paintbrush”) by Jarosław M. Gruzla shows:

W późne popołudnie pod akacjami błękit nieba.

Moje ciało rozpływa się w skupieniu.

Wypisy z ksiag użytecznych

poruszają, rozpalają płomień, jak niegdyś w poecie znad Wilii

Chińska fletnia.

Wesołe krzyki dzieci, gadanie wiatru, The cheerful shrieks of children, the talking cisza.
On a late afternoon

Under the acacias the blue of the sky.

My body evaporates in concentration

A Book of Luminous Things

moves, lights a flame

as once in the poet from the Vilia

The Chinese Flute.

wind, silence. 
Człowiek pod ciężarem wieków czyż coś takiego mogło się zrodzić pod chińskim pędzlem?

Nad Rzeka Żółtą liść spadł, mgła płynie, a pióra żurawi białe...
A man under the weight of centuries could something like this have been born under a Chinese paintbrush? By the Yellow River a leaf fell, the fog drifts and the crane feathers white...

(trans. by Marta Skwara)

The poem may be read both as a mimicry of Chinese poetics and as an illustration of the reasons for which, against all odds and language barriers, one attempts to translate such seemingly distant yet apparently close poems. According to Miłosz we do it in order "to jump the border between them and us to discover a human being, not so exotic as it might seem" (Miłosz, 1994: 270). That statement seems applicable to any presentation of foreign poetry, even poetry extremely difficult to translate: it does let us jump borders between different cultures.

The tradition of Polish prose will be dealt with along similar lines, both concerning its chronological development and its intertextual (intercultural) connections. Thus I will discuss Lalka ("The Doll") by Bolesław Prus, one of the masterpieces of the $19^{\text {th }}$ century realistic novel in Poland, both in the context of the earlier tradition of the Polish novel (dating back to the $18^{\text {th }}$ century) and in the context of European and transatlantic discussions and developments of the genre, of which Witold Gombrowicz's writings represent an internationally acknowledged example. Also female novelists will be analyzed as a part of my discussion of the development of the genre over the centuries, and over the cultures - from the $18^{\text {th }}$ century narratives by Elżbieta Drużbacka via the romantic prose by Narcyza Żmichowska to the renowned writers Maria Dąbrowska and Zofia Nałkowska in the $20^{\text {th }}$ century, and further on to various postmodernist female narratives. The multicultural aspect of Polish prose is closely connected with the fact that most of the Polish literary émigrés would write and publish only prose in various languages abroad (since for poetry one's own language is essential, as Miłosz, who lived in the US for over 30 years and never wrote a single poem in English, put it).

The treatment of drama - from its classical Renaissance shape to its grotesque $20^{\text {th }}$ century variations and its new intermedial forms in the $21^{\text {st }}$ century - will supplement my discussion of poetry and prose. In Romantic dramas 
by writers such as Adam Mickiewicz, Juliusz Słowacki, Zygmunt Krasiński, or Cyprian Norwid poetry played an essential role and was connected with the authors' poetic output, which was also true for symbolic theatre. Realistic drama, which was most successful in the form of comedy, got rid of poetry and poetic fantasy. For the masters of grotesque theatre however - Witkacy, Witold Gombrowicz, Sławomir Mrożek, Tadeusz Różewicz (each of them translated into many languages and staged all over the world now) - all the literary poetics, motifs and genres were essential as they were used to produce new literary universes. An especially strong line of tradition starts with Juliusz Słowacki's romantic theatre, based on intercultural relationships, intertextual devices, self-referential allusions and grotesque elements. That tradition was first continued at the beginning of the $20^{\text {th }}$ century by the visionary theatre of Stanisław Wyspiański, and then, in many plays, by Witkacy in the 1920s and 1930s. One of the motifs common to both Słowacki, Wyspiański and Witkacy - but put into a grotesque form only by the latter - is the dream. The dream is understood both as a prophetic state and as a fantastic world of its own, a world in which anything can happen. Such dreams are characteristic of Słowacki's character Salomea (from the play "Sen srebrny Salomei”, 1843 ("Salomea's Silver Dream"). In one of her dreams she can see "a red stain", the symbol of a bloody crime reminiscent of a famous vision of Lady Macbeth's, which subsequently acquires a deep meaning in the play. The dreams of Witkacy's characters, often called "bad dreams", are deprived of symbolic explanations and are repeated time after time, bearing more and more absurd meanings. Such are the dreams of Elza and of Fizdejko, the grotesque characters from Witkacy's intertextual play "Janulka, córka Fizdejki”, 1923 (“Janulka, the Daughter of Fizdejko"); the title alludes to a $19^{\text {th }}$ century Polish novel set in Lithuania. In one of the scenes, a ghost kills another ghost with "a real Winchester", which can evoke a sense of overwhelming black humor and absurdity, especially since the scene is followed by "a strange coincidence": a meeting of four identical dreams "called sometimes a miracle" (Witkiewicz 166). In fact, the "miracle" builds on a long theatrical tradition, in which Shakespeare, Calderon de la Barca, Słowacki who translated one of Calderon's dramas into Polish - and Wyspiański play eminent roles. Witkacy's travesty of la vida es sueno opens the motif towards the absurd. Later dramatists, like Tadeusz Różewicz and Tadeusz Kantor in the 
second half of the $20^{\text {th }}$ century, made use of Witkacy's achievements, adding new dimensions to what is now called performative theatre.

Since theatre has always been an intermedial art, it makes a good point of transition to the next chapter of the monograph, which will be devoted to intermediality in Polish literature, that is, to particularly interesting cases of close connections between literature, art, music and new forms of art (movies and new media). A consideration of intermediality appears especially important since existing introductions of Polish literature to international readers devote no special sections to literature which transcends literariness and crosses over towards other arts and media. Three major works can exemplify this. The first is Manfred Kridl's Survey of Polish Literature and Culture (1956), in many aspects still the richest and most comprehensive presentation of Polish literature up to the WWII. The second is Czesław Miłosz's somewhat personal History of Polish Literature (1969), widely disseminated due to the author's fame, and the third is a new collaborative work, Ten Centuries of Polish Literature (2004), which ambitiously extends the history of Polish literature but not really its scope. For example, the first religious song in Polish Bogurodzica (written down at the beginning of the $14^{\text {th }}$ century, but with an oral tradition dating back to the $13^{\text {th }}$ century), quoted and illustrated over the ages in many art works, including movies, is usually analyzed as a literary work but hardly ever comparatively studied within the Deesis icon/art motif. The presence of the song in later Polish literature and cinema is not even mentioned, despite the fact that a modern reader might be interested not only in reading about the song but also in listening to it and watching it being sung. In fact, many performances are now available on the Internet (e.g. https://www.youtube.com/watch?v= 3P2Pr6kUxtA).

Likewise, the poetic cycle Treny/ Threnoi by Jan Kochanowski, our major Renaissance poetic work, still being alluded to and paraphrased today, might be interpreted not only in the context of ancient and biblical motifs, but also within the context of European and Polish Renaissance funeral art. Such wider cultural background will be helpful in demonstrating the uniqueness of the cycle devoted to the poet's late daughter, a little girl (such a literary motif was unusual both for European literature and art until Romanticism). Romantic and modernist poetry in which strong connections with art and music are essential can also often be interpreted in an interesting manner in the context of European 
art and intercultural connections. Furthermore, artists who were both writers/ poets and painters (among them the aforementioned Stanisław Wyspiański, Bruno Schulz, and Witkacy), or playwrights, graphic artists and musicians (e.g. Bogusław Schaeffer), or writers and film makers (Stefan Themerson), or poets and art connoisseurs (e.g. Cyprian Norwid and Zbigniew Herbert), need to be presented in their double (or even triple) roles and have the intermedial aspects of their work discussed.

Since Poles consider themselves a nation of poets, not as much painters, the literary connections made between Polish literature and art are usually connections between Polish literature and European/World art. Thus Polish poetic ekphrasis, produced by Herbert, Różewicz, Miłosz or Szymborska, to mention only the most famous poets, mostly describes and discusses other nations' art - for example, Italian art in the case of Herbert, Dutch and German art in the case of Różewicz, Miłosz, or Szymborska (who also wrote poems on French art), and far Eastern or African art in the case of the avant-garde or the postmodern generation of poets. This feature may be particularly interesting for members of other cultures since it enables them to see connections between their own art and Polish literature and culture. It may be also important to point to such elements of the Polish intermedial literary tradition that concern common phenomena in modern culture like the emergence of the cinema in the first decades of the $20^{\text {th }}$ century. Tytus Czyżewski, a painter and a poet, reacted very early and aptly to the birth of the cinema and at the same time to the birth of mass culture. Due to his avant-garde language experiments his poems are not easy to translate, but one of his "cinema" poems can be put into English successfully and I believe it can be easily appreciated by members of different cultures who participate in the movie culture which, after all, operates according to the same basic mechanisms even today. Tytus Czyżewski’s "Sensacja w kinie", 1922 (“Sensation in the Cinema”) reads:

Kino Palace: mord $w$ Bombaju aju aju aju aju morze auto cztery drzewa ktoś na portiera się gniewa Ola Föns na nerwach gra mi Jak tu strasznie czuć śledziami
Cinema Palace: killing in Bombay

ay ay ay ay ay ay ay ay

the sea a car four oaks someone at a porter frowns Ola Föns gets on my nerves How awful a herring smells 
Pchła ugryzła Helę w łydkę Jakie on ma zęby brzydkie Ktoś nade mną stanął stoi Czy Pan Boga się nie boi Na miły Bóg niech pan siada Mia May z okna wypada Ona pewnie się zabije

już nie żyje już nie żyje czterej niosą ją lokaje nic jej nie jest wstaje wstaje żyje żyje żyje żyje co za sensacyjne chryje Pauza pauza niosą ciasta Niech pan zbytnio się nie szasta Panie niech mnie pan nie gniecie Bo jeszcze światło się świeci Dramat tajemnice kryje Czy on umrze czy ożyje W loży śmieje się Ko-ko-ta Film kurz nerwy trochę błota
A flea bit Hela's calf How ugly his teeth are Someone's stood at me and stands no care Aren't you afraid of God Sir Sit down for God's sake I am calling Mia May out of a window is falling She is sure to lose her life

no longer alive no longer alive four footmen carry her up she is fine gets up gets up alive alive alive alive what a sensational dive A Pause a pause they fetch pie Do not tussle as you try Do not press me come on The light is on still on still on In a drama secrets hide Will he die or revive In a box laughs Co-cotte Film dust nerves some rot

(trans. by Marta Skwara)

The interlinear translation may help foreign readers to follow a digital adaptation of the poem which is accessible online (http://ha.art.pl/czyzewski/ sensacja_w_kinie.html ). The adaptation may also serve as a presentation of the second life of poetry nowadays, which is a medial life.

In the concluding chapter of my monograph I will outline the situation after the Fall of Communism, when Polish literature - for the second time after the reestablishment of the independent Polish state in 1918 - was liberated from its patriotic duties. The new situation added novel dimensions to Polish literature. New themes and a new poetics began to be introduced, yet also a kind of uniformity arose, especially after Poland joined the European Union. Also, some authors of Polish origin are now believed to produce, for example, one of the so-called "new Swedish literatures" (nya svenska litteraturer) as well as Migrantenliteratur or internationelle Literatur. Nya svenska litteraturer is a concept being applied to literatures in the Swedish language created by immigrants, whereas Migrantenliteratur or internationelle Literatur is the German equivalent. An outstanding example of the latter is a novel on 
a typical Polish history experience by Christian Skrzyposzek entitled De vrije tribune (1983) which depicts the tragically grotesque everyday life in People's Poland. The novel was first published in Germany (where it was met with great interest), and only 15 years later in Poland, in the new democratic Poland of the late 1990s (where it received much less attention since the mechanisms of the totalitarian communist system seemed an old and overused topic for Poles, even if the genre was interestingly refreshed by the author). The new phenomenon of hybridized language also appeared, for instance in Dariusz Muszer's works. While translating his novel Die Freiheit riecht nach Vanille, published in Germany in 1999, he filled the Polish version Wolnośćpachnie wanilia (published in 2008) with various hybrid forms: quotations, imaginative translations of phrases and idioms, language calques, deconstructed motifs of the stranger and of foreignness, and various alienation effects. The same can be said about his latest novel Gottes Homepage, 2008 (God's Homepage) and its later Polish version (Homepage Boga, 2013) which critics associate with the tradition from Kurt Vonnegut, Georg Orwell and Stanisław Lem (a renowned Polish science-fiction writer often translated into foreign languages, especially prominent in German culture). Since Muszer's novel depicts atrociously manipulative mechanisms of the Internet epoch, it deals with problems concerning us all, Europeans and non-Europeans. Now more than ever, it seems to me, it is worth asking, and if possible answering, the question of what world literature is and what roles particular national literatures play in it. There is no better way of grappling with that question than by translating literature, presenting literature, interpreting it, putting it into comparative contexts and opening the floor for discussion.

\section{Works cited}

Brandes, Georg. "Weltliteratur." Trans. by H. Saussy. The Princeton Sourcebook in Comparative Literature. From the European Enlightenment to the Global Present. Eds. D. Damrosch, N. Melas, and M. Buthelezi. Princeton and Oxford: Princeton University Press, 2009. 61-66.

Czyżewski, Tytus. "Sensacja w kinie.” Wiersze i utwory teatralne. Tytus Czyżewski. Gdańsk: słowo/obraz terytoria, 2009. 81. 
Gruzla, Jarosław Maria. “Głębia zmierzona chińskim pędzlem.” Antologia nowej poezji polskiej. Eds. R. Honet and M. Czyżewski. Kraków: Zielona Sowa, 2004. 95-96.

Kridl, Manfred. Survey of Polish Literature and Culture. Trans. by O. Scherer-Virski. 'S-Gravenhage: Mouton, 1956.

Milosz, Czeslaw. The History of Polish Literature. London: The Macmillan Company, 1969.

---. Wypisy z ksiag użytecznych. Kraków: Znak, 1994.

---. A Book of Luminous Things. An International Anthology of Poetry. Edited and with an introduction by C. Milosz. San Diego-New York-London: Harcourt Brace, 1996.

Ten Centuries of Polish Literature. Trans. by D. Sax. Contributors G. Borkowska at al. Warszawa: Instytut Badań Literackich PAN, 2004.

Witkiewicz, Stanisław Ignacy. Dramaty. Vol. 3. Ed. J. Degler. Warszawa: PIW, 2004.

\section{How Can One Write National Literature History in a "Glocal" World? Remarks on the Writing of a Modern Polish Literature Handbook in English}

\section{Summary}

In this article I should like to explain how I plan to work on a one-volume English-language history of Polish literature that is supposed to address both foreign and Polish readers. While foreign readers should acquire some perspective on one of the relatively unknown European literatures, domestic readers should be helped to see their well-known literature from different cultural angles. I will discuss several issues connected with the writing of such a handbook, namely: existing ways of presenting Polish literature internationally, the inner mechanisms and the outer relationships of Polish literature, its local and global aspects (also in the case of immigrant literature), the increasing importance of discussing intertextuality and intermediality of the literature as well as new forms of hybridisation of literary language. My article is meant to illustrate and discuss some problems of presenting a "local" literature on the global literary-history market today.

Keywords: literary history, comparative literature, Polish literature, European literature, "glocality", intertextuality, intermediality

Słowa kluczowe: historia literatury, literatura porównawcza, literatura polska, literatura europejska, ,glokalnośc”, intertekstualność, intermedialność 